\title{
Managing Key Accounts in the Readymade Garments Industry: To What Extent Bangladeshi Companies Perform
}

\author{
Kawsar Ahmmed $^{1}$, Nor Azila Mohd. Noor ${ }^{2}$ \\ Received: May 1, 2018 Revised: June 10, 2018 Accepted: July 30, 2018
}

\begin{abstract}
With the paramount importance of key account management in business-to-business relationship, today companies are using this approach as a strategic weapon in their selling efforts targeted at the most important customers to solve their complex requirements with special treatment that eventually ensures both parties' financial and nonfinancial objectives. The aim of this paper is to investigate the level of key account management performance among the export-oriented readymade garments companies in Bangladesh with regards to company's experience in business, size of the company and key account serving capacity of the company. Using a questionnaire, data from 112 readymade garments companies in Bangladesh were collected and analyzed using descriptive analysis and ANOVA to test the level of key account management performance. Results show that the level of key account management performance by the garments companies did not vary by the company's experience in business and size of the company respectively. In contrast, the level of key account management performance was found to be different concerning high, medium, and low customer service capacity. Apparently, companies with big number of customers show better performance than companies with small number of customer. Implications for this study are discussed along with suggestions for future research avenues.
\end{abstract}

Keywords: Key Account Management Performance, Business-to-Business, Relationship Marketing, Garments Industry, Bangladesh.

JEL Classification Code: M30, M31.

\section{Introduction}

Efficient customer management with endless efforts makes the marketer's position enduring in the marketplace, creates its position impregnable and ensures the sustained competitive advantage. The situation is more critical when companies require to manage customer with strategic importance. These customers are key for the supplying company and serving them with utmost sincerity is indispensable as they have greater impact on the supplier's business. Hakansson and Snehota (1995) mention that

1 First Author and Corresponding Author. Associate Professor, School of Business and Economics, United International University, Bangladesh [Postal Address: United City, Madani Avenue, Badda, Dhaka- 1212 Bangladesh]

E-mail: kahmed.ba@gmail.com

2 Professor of Marketing, Othman Yeop Abdullah Graduate School of Business, University Utara Malaysia, Malaysia

E-mail: azila@uum.edu.my "most industrial companies have only a few customers and suppliers that account for a major part of their total sales and purchases. These and relationships to third parties are decisive for the performance of the company whatever various measures of performance one might use." Workman, Homburg, and Jensen (2003) suggest for execution of added functions and/or designation of special executives aimed at the organization's most significant customers. Account management directed towards key customers in the business markets that can be perceived as a useful execution of durable buyer/seller relationships (Gosselin \& Heene, 2005) where perennial interaction takes place between seller and key account. Key account management has its long tradition and business organizations use it in some form (Millman, 1996; Millman \& Wilson, 1995; Napolitano, 1997; Shapiro \& Moriarty, 1980) and it stresses on create, nurture and maintenance of the long-term relation with customers (Sharma, 2006). From an array of terms used in this field we have taken key account management and define it as a supplier company initiated relational 
approach targeted at the most important customers to solve their complex requirements with special treatment that eventually ensures both parties' financial and nonfinancial objectives (Ahmmed \& Noor, 2012).

Performance relates to the assurance of efficiency and effectiveness in the completion of a particular task which results in expected level of outcomes. In the field of marketing, usually sales volume, profit margin, return on investment made by marketer and choice among brands by the customers determine performance (Meyvis \& Janiszewski, 2004; Ofek \& Sarvary, 2003). Sherman, Sperry, Reese, and Reese (2003) mention that key account management performance is the undertaking of firm-wide initiative by which firms systematically and proactively deliver strategic solutions to multiple contacts at targeted accounts with a purpose of capturing a dominant share over time.

The aim of this paper is to investigate the level of key account management performance with survey data collected from the readymade garments industry in Bangladesh. Within a very limited time garments industry has become a major player in the economy of Bangladesh and now second behind only China among the world's largest exporters of apparel, with a $\$ 20$ billion-a-year garment industry (Breed, 2012). This sector solely represents 82.05 percent of the country's export earnings in the fiscal year of 2015-2016 (Bangladesh Garment Manufacturers and Exporters Association-BGMEA, 2016). At present this industry is availing about thirty categories of apparels for Wal-Mart, Levi Strauss, Zara, Tesco, Gap, Carrefour, Metro, Marks and Spencer, Kohl's, JC Penney, H\&M, Tommy Hilfiger and other key accounts (Rahman, 2010). Their purchase volume, specific requirements, reference power and other superiorities like research and development capability in fashion and design, capability to enter into untapped new market giving them asymmetrical edge in the buyer-seller relationship in the Bangladesh garments sector (Huq, 2006). Although low labor cost along with efficient producers and good needlework has made Bangladesh an attractive destination for major buyers of apparel (Murshid, Zohir, Ahmed, Zabid, \& Mehdi, 2009), the challenges facing this sector are formidable (Rahman, 2010). Rahman and Mirdha (2009) mention that the garment industry is the backbone of Bangladesh's fledgling economy and any shocks to its system could prove fatal for the growth of the nation and resulting economy of Bangladesh will be three times poorer (Haque, 2010). Therefore, finding out the mechanism for serving these customers are vital for the garments companies.
The studies of Sharma (2006) and Zupancic (2008) explore that what factors lead to successful or unsuccessful key account management and what are the impact of successful key account management strategy is still lacking. Similarly, Millman (1996) explores that in the academic field the area of key account management is under researched and its efficacy is only partially understood. Furthermore, there is relatively little research on KAM in emerging and developing economies (LDCs) (Al-Husan \& Brennan, 2009) and suppliers in Asia (Murphy \& Li, 2015). Guesalaga and Johnston (2010) explore that empirical KAM research is dominated by USA (53\%) and Europe (40\%) perspectives, with Asia representing just $5 \%$ of studies. As a result, appropriate theoretical background is missing (Gosselin \& Bauwen, 2006; Murphy \& Li, 2015) and little guidance has emerged on how to better ensure key account management performance in the eastern context in particular Bangladesh.

Therefore, it becomes critical for garments owners to understand how the inherent characteristics of companies like experience, size and capacity affect key account management performance in the business-to-business context. Focusing on the impact of the company's experience in business, size of the company and capacity of the company on key account management performance may help management improve the performance of their key account relationship. Eventually, this research addresses the issue of "what is the level of key account management performance among Bangladeshi garments companies with regard to company's experience in business, size of the company and key account serving capacity?"

Table 1 shows the three basic characteristics of garments companies of Bangladesh. These three features are again divided into three groups based on their level namely high, medium and low. First characteristic is experience in business that is based on the company's establishment year. Second characteristic is size that refers to the company's total number of employees. Third characteristic is capacity of the company that is determined on the basis of the key account service capacity of the individual company.

The remainder of the paper is structured into five sections. Next section discusses relationship marketing and key account management. Explanations on key account management performance are given in section three. Section four presents the discussions on methodology that includes sample, data collection, the instrument used and analysis and results. Study discussions are given in section five. Finally, section six discusses the implications and suggestions for future research direction. 
Table 1: Characteristics of the Responding Garments Companies

\begin{tabular}{|c|c|c|c|}
\hline Characteristics/Particulars & Range & Number of Companies & Total Companies \\
\hline \multirow{3}{*}{$\begin{array}{c}\text { Experience in Business (Company } \\
\text { Establishment Year) }\end{array}$} & 1-12 Years (Low) & 47 & \multirow{3}{*}{112} \\
\hline & 13-24 Years (Medium) & 41 & \\
\hline & 25 Years and Above (High) & 24 & \\
\hline \multirow{3}{*}{$\begin{array}{l}\text { Size of the Company } \\
\text { (Number of Employees) }\end{array}$} & 1-1800 Employees (Small) & 73 & \multirow{3}{*}{112} \\
\hline & 1801-3600 Employees (Medium) & 14 & \\
\hline & 3601 Employees and Above (Large) & 25 & \\
\hline \multirow{3}{*}{$\begin{array}{l}\text { Capacity of the Company } \\
\text { (KA Serving per Year) }\end{array}$} & 1-4 Key Customers (Low) & 44 & \multirow{3}{*}{112} \\
\hline & 5-8 Key Customers (Medium) & 35 & \\
\hline & 9 Key Customers and Above (High) & 33 & \\
\hline
\end{tabular}

\section{Relationship Marketing and Key Account Management}

The area covered by relationship marketing is vast that incorporates all kinds of commercial associations, not just customers (Morgan \& Hunt, 1994) whereas key account management confines itself on relationships with the important customers of supplying companies (McDonald, 2000). Hakansson and Snehota (1995) mention that "most industrial companies have only a few customers and suppliers that account for a major part of their total sales and purchases. These and relationships to third parties are decisive for the performance of the company whatever various measures of performance one might use." According to the Pareto principle, it is immutable business fact that $80 \%$ of revenue comes from $20 \%$ of marketer's customers (Bunkley, 2008). This notion creates the basis for key account management approach where this strategy acts as the best way of ensuring repeat purchase, additional purchases and referral to other customers like them from the context of readymade garments industry of Bangladesh. McDonald (2000) termed the key account management approach as the natural extension and newer discipline of relationship marketing that focuses on fulfilling customer requirements in the business-to-business contexts. Yip and Madsen (1996) termed it as the new frontier in the field of relationship marketing. Sharma (2006) views key accounts management as the linkage between buyer-seller in a lengthy relational context and weights the formation, cultivate and upholding of stronger bonds with buyers.

Spencer (2005) mentions that the role of key account management is considered to be that of understanding the characteristics and needs of these key customers, then adapting the supplier organization to better serve them, with a view to optimizing on revenues. While traditional marketing approaches has given importance on exchange of goods and services and meeting customer needs, key account approaches is devoted to identify customer specific requirements and a consideration of satisfying customer needs (Sharma, 2003). Jackson (1985) highlights that fruitful relationship marketing with these customers involves doing a huge number of activities accurate, constantly, over the period of time.

\section{Key Account Management Performance}

In general, performance means an efficient completion of something that comes up with expected outcomes for which efforts have been rendered. In marketing performance is determined by the sales volume, profit margin and return on the investment made by the marketer (Ofek \& Sarvary, 2003). For our study, we have taken performance in key account management strategy as the attainment of goals for both key buyer and seller over a long-period of time in the key account relationship. In the business-to-business relationship, key account management approach is practiced with the strategically important customer. To ensure the greater degree of key account management performance various factors and forces exert influence on it. A proper customer orientation helps the suppliers to know key customer properly and facilitates them to serve key customer needs well that in turn ensures the performance in key account program and organizational outcome performance. In the business to business arena, customer perception about the key account management approach affects its performance, because their positive perception influence them to be receptive as long as the relationship does not create any disadvantage for them and develops commitment toward the program (Pardo, 1997). When the partnership between buyer and seller is strong enough, it creates competitive advantages on the field of opportunities to add value and reduce costs on both sides of the equation (Napolitano, 1997). 


\section{Methodology}

\subsection{Sample and Data Collection}

Readymade garments industry in Bangladesh was the population for the present study. The unit of analysis was garments manufacturer and merchandising manager of the respective manufacturer represented the individual garments company. Merchandising managers of the respective companies were chosen for several reasons. Firstly, merchandising manager represents garments manufacturer before the key customers in their procurement process. Secondly, they have the real life knowledge of dealing with the key accounts. Thirdly, they act as boundary spanner between the firm and key accounts. Finally, they have access to the top management regarding various issues like approval, access for resources etc. required to serve the customers purposes properly and at the same time ensure the organizational interest.

Based on the list available on BGMEA website, among the 3920 garments companies, about 2693 companies are located in Dhaka city representing $68.9 \%$ companies. Due to the majority of the companies located in Dhaka city, this research only considered the companies located in Dhaka city for data collection. Following the suggested table by Krejcie and Morgan (1970) 336 companies are taken as sample size for the study to administer questionnaire. However, to ensure the minimum response rate and taking into account the fact that survey research generates poor response rate, researcher distributed 600 questionnaires to the selected garments companies.

The study used systematic random sampling technique that assures known and equal probability of selection of each element in the study population which makes it basically equivalent to simple random sampling technique (Black, 2010) and is a simple, flexible and versatile form of probability sampling technique (Cooper \& Schindler, 2006). However, it is ensured that any hidden pattern of traits in the population is absence because the given population is logically homogeneous which is necessary to ensure the sample randomness (Black, 2010). In time of distributing the self-administered questionnaire a cover letter was accompanied that socialized the responding organization about the purpose of study, request for prompt response and an assurance of not disclosing the information provided and maintenance of anonymity. To maintain the parsimony of responses and assess their suitability, interested companies in this survey were finally selected and interviewed with the following criterions.

- Consideration of a company's most familiar key account customer for profits or importance;
- Companies having a single point of contact, a team, or a special department like merchandising department in place to serve this key account customer;

- Company should sell garments products directly to buyers or through its own buying house, and

- Representative person of the responding company must be a practitioner involved with key account management practices.

Some companies were discarded because they sell their garments products through independent buying houses and some others produce garments on sub-contact basis where they take orders from big companies and finish and supply quantity and get some margins. Although these types of big companies were being seemed key customer for the small sub-contact supplier, but getting these sub-contact are not constant and very competitive. Eventually, a total of 112 finished questionnaires were returned within a period of 7 months from the 600 companies that represented an $18.7 \%$ response rate. Previous researches show various rate like $23.3 \%$ from both products and services industry in US and Germany gathered through mail survey (Homburg, Workman, \& Jensen, 2002), 18.6\% from both products and services industry in North America and Western Europe collected through online questionnaire survey (Shi, White, Zou, \& Cavusgil, 2010), 16.5\% from both products and services industry in Germany gathered through mail survey (Wengler, Ehret, \& Saab, 2006), 23.3\% from both products and services industry in US and Germany collected through mail survey (Workman et al., 2003), 20.8\% from both products and services industry in Europe and North America collected through mail survey (Zupancic \& Müllner, 2008). Therefore, the response rate for the present study is comparable to those of previous studies. As the questionnaires were administered personally that generally elicit a substantially complete response (Hansen \& Hurwitz, 1946), errors were not evident to reject any questionnaire. Thus, all filled questionnaires were kept and considered suitable for data analysis.

\subsection{The Instrument}

Key account management performance was measured using one dimension borrowed from the study of Workman et al. (2003) scale that was derived from Irving (1995) scale. The instrument consists of seven items and minor modification on wording was made to make the items suitable for the current study. For this dimension, individual item was scored on 5 point Likert scale ranging from " $1=$ strongly disagree" to " $5=$ strongly agree". The internal reliability reported by Workman et al. (2003) was 0.85. In comparison to the normal accounts organizations were 
asked to rate themselves in terms of various issues as depicted in Table 2.

Table 2: Key Account Management Performance Measure

Items
Compared to normal account, our performance with this
key accounts in relation to achieving mutual trust is high
Our performance with this key accounts in relation to
achieving information sharing is high
Our performance with this key accounts in relation to
achieving a reputation of fair dealing is high
Our performance with this key accounts in relation to
achieving investments into the relationship is high
Our performance with this key accounts in relation to
maintaining long-term relationship is high
Our performance with this key accounts in relation to
reducing conflicts is high
Our performance with this key accounts in relation to
meeting sales targets and objectives is high
Source: Adapted from the study of Workman et al. (2003)

\subsection{Data Analysis and Results}

To see the level of key account management performance both descriptive analysis and ANOVA test were done.

\subsubsection{Descriptive Statistics}

The results of descriptive statistics for the variable are shown in the following Table 3. Company establishment year, customer serving capacity and number of employees were in the ratio scale and key account management performance scale was measured with a five-point Likert scale. For easy interpretation of the results of descriptive analysis, the rage of five-point Likert scale were classified into three equal size classes namely low, moderate and high. Thus, values of lower than $2.33[4 / 3+$ lowest value (1)] is treated as low; values of 3.67 [highest value (5)-4/3] is taken as high and values between these two extreme treated as moderate. Mean value of 4.1059 with standard deviation of .41116 for key account management performance indicates that firms show high level of performance in their key account management approach as evident in the above Table 3.

Table 3: Descriptive Statistics for Key Account Management Performance

\begin{tabular}{|c|c|c|}
\hline Dimensions (Variable) & Mean & SD \\
\hline Key Account Management Performance & 4.1059 & .41116 \\
\hline Valid N (list wise) & \multicolumn{2}{|c|}{112} \\
\hline
\end{tabular}

Note: $\mathrm{SD}=$ Standard deviation .

\subsubsection{Analysis of Variance (ANOVA)}

To address the research question that is "what is the level of key account management performance among Bangladeshi garments companies?" Above Table 3 shows the mean and standard deviation of the key account management performance among responding organizations. Companies tend to show high level of performance in their practice of key account management approach which is expressed through the mean values of 4.10 . Statistically the variation of key account management performance among companies is low as expressed by the standard deviation of 0.41 .

The differences in the level of key account management performance among the garments companies were explored in terms of company's experience in business (company establishment year), size of the company (number of employees) and capacity of the company (KA serving per year). The scores on company age, customer service capacity and company size are grouped into three categories, which are for company age and customer service capacity -low, medium and high and for company size -small, medium and large.

Table 4: Key Account Management Performance by Company Experience in Business, Size of the Company and Capacity of the Company

\begin{tabular}{|c|c|c|c|}
\hline Independent Variable & Categories & Mean & F-value(p value) \\
\hline Experience in Business & Low (1-12 years) & 4.0461 & .517 \\
(Company Establishment Year) & Medium (13-24 years) & 4.0457 & $(.597)$ \\
\hline Size of the Company & High $(\geq 25$ years) & 4.1424 & .870 \\
(Number of Employees) & Medium (1801-3600 employees) & 3.0674 & $(.422)$ \\
\hline Capacity of the Company & Large ( $\geq 3601$ employees) & 4.1300 & 8.733 \\
(KA Serving per Year) & Low (1-4 customers) & 4.0180 & 3.9155 \\
\end{tabular}

Note: ${ }^{*}<.05 ; N=112$ 
Analysis of variance (ANOVA) was used to judge the variations among these variables. Above Table 4 summarizes the results of the test. From the result it is evident that the level of key account management performance by the garments companies did not vary by company age $(F=.517 ; p=.597)$ and company size $(F=.870$; $p=.422$ ). But with regards to customer service capacity, the level of key account management performance was found to be different $(F=8.733 ; p=.000)$. The post-hoc test shows that responding companies with capacity of serving 1-4 customers show less key account management performance than those with customer service capacity of 9 and more customers. Similarly, companies with capacity of serving 9 and more customers are found to show significantly more key account management performance than those with serving capacity of 5-8 customers.

In sum, the level of key account management performance among garments companies in Bangladesh is encouraging. Responding companies with different age, serving capacity and size are found to show similar level of key account management performance. Companies with capacity of serving 1-4 customers show less key account management performance than those with capacity of serving 9 and more customers. Companies with capacity of serving 9 and more customers are found to show significantly more key account management performance than those with serving capacity of 5-8 customers in the garments industry in Bangladesh.

\section{Discussion}

In response to the research question, this study explored that level of key account management performance among garments companies in Bangladesh is very high. In consistent with the study objective, it can be interpreted that it is a firm-wide initiative where garments companies systematically and proactively deliver strategic solutions to targeted key buyers with the purpose of capturing a dominant share over time from them. Garments companies engage in such activities which make them capable enough to fulfill key customers requirements properly. At the same time they avoid those activities and behavior that act negatively between them to build and maintain a satisfactory win-win relationship.

One plausible explanation behind this high performance of key account management strategy among garments companies is growing competition from both internal and external strong players as well as high customer demand. Presently about 7,000 (including both member and nonmember companies of BGMEA) garment factories are producing different types of apparels and serving international key retail accounts like Wal-Mart, Levi Strauss, Zara, Tesco, Gap, Carrefour, Metro, Marks and Spencer, Kohl's, JC Penney, H \& M and Tommy Hilfiger (Haque, 2010; Rahman, 2010). Because of their high purchase volume, reference power and other superiority like research and development capability in fashion and design, capability to enter into new untapped market, these customers are more demanding, requiring full package offering, careful about the margins, expect diversified products and services and observant about compliance requirements (Huq, 2006). Likewise, today strong competitive garments manufacturers from China, Pakistan and others countries with their high end product manufacturing expertise setting factories or moving their factories to Bangladesh (Haider, 2007; Nuruzzaman \& Haque, 2009) because low wages make Bangladesh an attractive factory market (Krulick, 2012; Anbarasan, 2012; Bangladesh Textile Today, 2011). Given these challenges, garments companies are paying more attention to realize customer needs properly, continuously improving their operational efficiency that are essential for meeting those high needs of customers in a customized manner.

As companies are practicing their key account management strategy over time, they are becoming more proficient in selling their finished garments through paying a keen attention to the buyers' need. This in turn adds value to the customer business, build a satisfactory business relationship with the key customers as well as ensure a steady growth of the focal company. This result is similar to Shi et al. (2010) and Workman et al. (2003) studies that found high level of key account management effectiveness among companies dealing with global key accounts in North America and Western Europe.

The present study found that level of key account management performance does not vary by the year of experience in the business. This is because in the garments industry fashions changes very frequently. Huq (2006) contended that in the garments industry it requires to respond to rapid changes in customer demand because fashion requires quick turnaround period for women, who alter style and color six times and men three times per year. Eventually experience with one season does not extended to the next season because of quick changes in fashions in the readymade garments. As perspective changes over time, one customers experience cannot be applied later on for the other customers.

Furthermore, the size of the company based on number of employees they have did not show any difference in key account management performance. The plausible reason is that in time of making business relationship Bangladeshi garments companies consider their human capability. This means, companies with small number of employees tend to 
make contact with small key customers compared to those companies with large workforce build business relationship with large key buyers. Thus, this type of strategy makes them fit enough to meet the key customers' requirements properly as promised. Another opposite reasons is that if any company make contact with large buyer, irrespective its small size, it can manage the supply in due time through sub-contract with other garments companies who have no direct key customers.

From the findings, it is evident that significant differences on key account management performance are available among companies with their serving capacity of total number of key account customers. Here companies serving more key customers show better key account management performance compared to those companies serving small number of key buyers. In the garments industry, buyers place their order to suppliers with their unique requirements and specifications. When a company deals with more customers, it can know about diversified requirements that help the supplier to acquire vast working knowledge and develop customer database. Eventually this knowledge gives the companies, with more key account customers, a superiority edge in key account management performance compared to those companies serving small number of key customers. This is because cross-utilization of customers' intelligence is possible when more customers are available in the business relationship.

\section{Implications and Suggestions for Future Research Direction}

Based on the empirical research, we are able to establish the relationship between company's experience in business (company establishment year), size of the company (number of employees) and capacity of the company (KA serving per year) and key account management performance. It is evident that the level of key account management performance among garments companies in Bangladesh is encouraging. Responding companies with different experience, size and serving capacity are found to show high level of key account management performance. In case of companies with capacity in serving key customer they vary. Companies with big number of customers show better performance than companies with small number of customer. An interesting implication for this result is that garments firms can utilize their combined knowledge garnered from the serving more and more customers. Because more responsibility from different angles and multifaceted customer experience bring suitable capabilities to garments companies necessary to deal with varied challenges.
On the part of the garments companies, although it is seen that they are showing greater performance in key account management, top management should continue to enforce the efforts so that merchandising departments show and upgrade their performance in serving key accounts. This is because customers' demands are changing, fact of globalization and strong global competitors are present and incoming of more foreign companies in the industry. In this regard only those companies will able to compete in the race which will acquire the ability to reach and tackle the customers' requirements with superior value. This justifies the continuous effort of the garments companies to uplift their key account management skills so that they can secure greater key account management performance which in turn will ensure higher outcome performance from key accounts.

Several limitations of this study open the door for further exploration in the field of key account management. We did not deal with other demographic variables and various antecedents and their individual impact on key account management performance. Future research can deal with the impact of other variables like key account-supplier collaborations and exchange of personnel between key account and supplier company on key account management performance.

\section{References}

Ahmmed, K., \& Noor, N. A. M. (2012). Key account management: Towards a multidimensional definition. East Asian Journal of Business Management, 2(1), 5-13.

Al-Husan, F. B., \& Brennan, R. (2009). Strategic account management in an emerging economy. Journal of Business \& Industrial Marketing, 24(8), 611-620.

Anbarasan, E. (2012). Chinese factories turn to Bangladesh as labour costs rise. Retrieved December 15, 2017 from http://www.bbc.co.uk/news/business-19394405

Bangladesh Garment Manufacturers and Exporters Association; BGMEA (2016). Trade Information. Retrieved December 15, 2017 from http://bgmea.com.bd/home /pages/Tradelnformation

Bangladesh Textile Today (2011, Jul-Aug). Pakistan textile manufacturers moving to Bangladesh. Retrieved December 15, 2017 from http://www.textiletoday.com.bd/ index.php?pid=magazine_news\&issue=4\&year=2011\&typ $\mathrm{e}=\mathrm{Y}$

Black, K. (2010). Business Statistics for Contemporary Decision Making (6th ed.). New York, NY: John Wiley \& Sons.

Breed, A. G. (2012). Why Asian Garment Factories Remain Dangerous. The Irrawaddy Magazine. Retrieved 
December 15, 2017 from http://www.irrawaddy.org/ archives $/ 21108$

Bunkley, N. (2008, March 3). 'Joseph Juran, 103, Pioneer in Quality Control, Dies'. New York Times.

Cooper, D. R., \& Schindler, P. S. (2006). Marketing Research. New York, NY: McGraw-Hill.

Gosselin, D. P., \& Bauwen, G. A. (2006). Strategic account management: Customer value creation through customer alignment. Journal of Business \& Industrial Marketing, 21(6), 376-385.

Gosselin, D., \& Heene, A. (2005). Strategic implications of a competence-based management approach to account management. Research in Competence-based Management, 1, 177-200.

Guesalaga, R., \& Johnston, W. (2010). What's next in key account management research? Building the bridge between the academic literature and the practitioners' priorities. Industrial Marketing Management, 39(7), 10631068.

Haider, M. Z. (2007). Competitiveness of the Bangladesh ready-made garment industry in major international markets. Asia-Pacific Trade and Investment Review, 3(1), 3-27.

Hakansson, H., \& Snehota, I. (1995). Developing Relationships in Business Networks. London: Routledge.

Hansen, M. H., \& Hurwitz, W. N. (1946). The Problem of Non-Response in Sample Surveys. Journal of the American Statistical Association, 41(236), 517-529.

Haque, S.A. (2010, October). The Road to Recovery. Forum, 3(9). Retrieved December 10, 2017 from http://www.thedailystar.net/forum/2010/October/road.htm

Homburg, C., Workman, J. P., \& Jensen, O. (2002). A configurational perspective on key account management. Journal of Marketing, 66(2), 38-60.

Huq, A. (2006, February 4). Success one stitch at a time. The daily Star. Retrieved December 10, 2017 from http://www.thedailystar.net/suppliments/2006/15thanniv/c elebrating_bd/celeb_bd10.htm

Irving, Ed. (1995). Marketing quality practices. Unpublished PhD Dissertation. University of North Carolina, Chapel Hill.

Jackson, B.B. (1985). Winning and Keeping Industrial Customers. New York, NY: Lexington Books.

Krejcie, R., \& Morgan, D. (1970). Determining sample size for research activities. Educational and Psychological Measurement, 30, 607-610.

Krulick, A. (2012). Bottom line of business set stage for tragic factory fire in Bangladesh. Retrieved December 15, 2017 from http://www.debt.org/blog/bottom-line-ofbusiness-set-stage-for-tragic-factory-fire-in-bangladesh/

McDonald, M. (2000). Key Account Management-A Domain Review. The Marketing Review, 1(1), 15-34.
Meyvis, T., \& Janiszewski, C. (2004). When are broader brands stronger brands? An accessibility perspective on the success of brand extensions. Journal of Consumer Research, 31(2), 346-57.

Millman, T. F. (1996). Global key account management and systems selling. International Business Review, 5(6), 631645.

Millman, T., \& Wilson, K. (1995). From key account selling to key account management. Journal of Marketing Practice: Applied Marketing Science, 1(1), 9-21.

Morgan, R. M., \& Hunt, S. D. (1994). The commitment-trust theory of relationship marketing. Journal of Marketing, 58(3), 20-38.

Murphy, W. H., \& Li, N. (2015). Key account management in China: Insights from a Chinese supplier. Journal of Business Research, 68(6), 1234-1241.

Murshid, K. A. S., Zohir, S. C., Ahmed, M., Zabid, I., \& Mehdi, A. (2009). The global financial crisis implications for Bangladesh. BIDS-PRP Working Paper Series No. 1. Dhaka: The Bangladesh Institute of Development Studies.

Napolitano, L. (1997). Customer-supplier partnering: A strategy whose time has come. Journal of Personal Selling and Sales Management, 17(4), 1-8.

Nuruzzaman, \& Haque, A. (2009). Lead Time Management in the Garment Sector of Bangladesh: An Avenue for Survival and Growth. European Journal of Scientific Research, 33(4), 617-629.

Ofek, E., \& Sarvary, M. (2003). R\&D, marketing, and the success of next-generation products. Marketing Science, 22, 355-370.

Pardo, C. (1997). Key account management in the business to business field: the key account's point of view. Journal of Personal Selling and Sales Management, 17(4), 17-26.

Rahman M.M. (2010, October). Living wage is not just wages. Forum, 3(9). Retrieved December 10, 2017 from http://www.thedailystar.net/forum/2010/October/living.htm

Rahman, N., \& Mirdha, R. U. (2009). The Garments of Recession'. Star Weekend Magazine, 8(64). Retrieved April 10, 2017 from http://www.thedailystar.net/magazine/ 2009/04/02/cover.htm

Shapiro, B.P., \& Moriarty, R.T. (1980). National Account Management. MSI Report No. 80-104. Cambridge, MA: MSI.

Sharma, A. (2006). Success factors in key accounts. Journal of Business and Industrial Marketing, 21(3), 141150.

Sharma, N. (2003). The role pure and quasi-moderators in services: An empirical investigation of ongoing customerservice-provider relationships. Journal of Retailing and Consumer Services, 10(4), 253-62. 
Sherman, S., Sperry, J., Reese, S. J., \& Reese, S. (2003). The seven keys to managing strategic accounts. McGrawHill.

Shi, L. H., White, J. C., Zou, S., \& Cavusgil, S. T. (2010). Global account management strategies: Drivers and outcomes. Journal of International Business Studies, 41(4), 620-638.

Spencer, R. (2005). Strategic Management of Customer Relationships - A Network Perspective on Key Account Management. Unpublished PhD Dissertation. Uppsala University, Sweden.

Wengler, S., Ehret, M., \& Saab, S. (2006). Implementation of key account management: Who, why, and how? An exploratory study on the current implementation of key account management programs. Industrial Marketing Management, 35(1), 103-112.
Workman, J. P., Homburg, C., \& Jensen, O. (2003). Intraorganizational determinants of key account management effectiveness. Journal of the Academy of Marketing Science, 31(1), 3-21.

Yip, G. S., \& Madsen, T. L. (1996). Global account management: the new frontier in relationship marketing. International Marketing Review, 13(3), 24-42.

Zupancic, D. (2008). Towards an integrated framework of key account management. Journal of Business and Industrial Marketing, 23(5), 323-331.

Zupancic, D., \& Müllner, M. (2008). International Key Account Management in Manufacturing Companies: An exploratory approach of situative differentiation. Journal of Business-to-Business Marketing, 15(4), 455-75. 